Article

\title{
Enhanced Nitrogen Removal of Steel Rolling Wastewater by Constructed Wetland Combined with Sulfur Autotrophic Denitrification
}

\author{
Tao Zheng ${ }^{1,2}$, Xiaohu Lin ${ }^{1}{ }^{\mathbb{C}}$, Jingcheng $X u^{1,3, *}$, Jie Ren ${ }^{1,4}$, Danyan Sun ${ }^{1}$, Yunhui Gu ${ }^{1}$ and Juwen Huang ${ }^{1,3}$ \\ 1 State Key Laboratory of Pollution Control and Resource Reuse, Key Laboratory of Yangtze Water \\ Environment, Ministry of Education, College of Environmental Science and Engineering, Tongji University, \\ Shanghai 200092, China; taotaozheng@163.com (T.Z.); tjhjxhlin@tongji.edu.cn (X.L.); \\ renjie_cathy@163.com (J.R.); cherrysdy@163.com (D.S.); guyunhui@tongji.edu.cn (Y.G.); \\ jwhuang@tongji.edu.cn (J.H.) \\ 2 Tongji Architectural Design (Group) Co., Ltd., Shanghai 200092, China \\ 3 Shanghai Institute of Pollution Control and Ecological Security, Shanghai 200092, China \\ 4 East China Architectural Design \& Research Institute Co., Ltd., Shanghai 200011, China \\ * Correspondence: xujick@tongji.edu.cn; Tel.: +86-021-6598-2010
}

Citation: Zheng, T.; Lin, X.; Xu, J.; Ren, J.; Sun, D.; Gu, Y.; Huang, J.

Enhanced Nitrogen Removal of Steel Rolling Wastewater by Constructed Wetland Combined with Sulfur Autotrophic Denitrification. Sustainability 2021, 13, 1559. https://doi.org/10.3390/su13031559

Academic Editor: Andreas Angelakis Received: 31 December 2020

Accepted: 27 January 2021

Published: 2 February 2021

Publisher's Note: MDPI stays neutral with regard to jurisdictional claims in published maps and institutional affiliations.

Copyright: (c) 2021 by the authors. Licensee MDPI, Basel, Switzerland. This article is an open access article distributed under the terms and conditions of the Creative Commons Attribution (CC BY) license (https:// creativecommons.org/licenses/by/ $4.0 /)$.

\begin{abstract}
Constructed wetlands (CWs), an ecological treatment technology, is suitable for advanced treatment, but has an unsatisfying denitrification performance for steel rolling wastewater with low $\mathrm{C} / \mathrm{N}$ ratio. This study combined sulfur autotrophic denitrification (SAD) with conventional constructed horizontal subsurface flow wetlands to treat steel rolling wastewater, exploring the feasibility of applying SAD to enhance the denitrification performance of CWs. The reactor consists of two sections, one filled with manganese sand and gravel $\left(\mathrm{HF}_{\mathrm{C}}\right)$ and another filled with ceramic, sulfur, and lime $\left(\mathrm{HF}_{\mathrm{SAD}}\right)$. Results showed that $\mathrm{HF}_{\mathrm{C}}$ had a good performance on removing turbidity, $\mathrm{DO}$, $\mathrm{COD}$, and $\mathrm{TP}$, while the average removal efficiency of total nitrogen (TN) in $\mathrm{HF}_{\mathrm{C}}$ was just $25.6 \%$. On this basis, $\mathrm{HF}_{\mathrm{SAD}}$ could remove $45.6 \%$ of $\mathrm{TN}$ subsequently, whose denitrification rate was $4-6$ times as high as that of $\mathrm{HF}_{\mathrm{C}}$. Increasing hydraulic retention time could improve removal efficiency of contaminants in $\mathrm{HF}_{\mathrm{C}}$ and $\mathrm{HF}_{\mathrm{SAD}}$ in different degrees. The analysis of microbial community structure, observation results of fillers and monitored sulfate all provided proofs for the occurrence of SAD. CWs combined with SAD can be applied in the treatment of steel rolling wastewater with low carbon, which can provide reference for ecological wastewater treatment, water saving, and recycling in iron and steel enterprises.
\end{abstract}

Keywords: advanced treatment; constructed wetland; ecological treatment; recycling; steel rolling wastewater; sulfur autotrophic denitrification

\section{Introduction}

The iron and steel industry is one of the pillar industries of China's national economic development, with its productivity ranking first steadily in the whole world in recent years [1,2]. In the steel production process, as great quantity of freshwater required and wastewater emitted, it's significant to improve water recycling for improving the sustainability of iron and steel industry. Steel rolling, coking, and iron exchange are several significant processes in the iron and steel enterprises, in which an overwhelming majority of wastewater emits [3]. After two-stage treatment, these kinds of wastewater are relatively stable and considerable in terms of quality and quantity [4], with great potential of advanced treatment and reuse, being a prominent part of saving water resources in iron and steel enterprises.

With the improvement of wastewater effluent quality standards and the large demand of water resource in iron and steel enterprises, advance treatment and reuse of steel rolling wastewater become more important. The dual-membrane, advanced oxidation and 
biological technology, and alternative advanced treatment processes have been studied and applied [5-7], with satisfying performance but great difficulty, high investment, and large energy consumption. As a type of ecological wastewater treatment technology, constructed wetlands have been applied in advanced treatment of industrial wastewater, due to the advantages of stable effluent quality, low running cost, convenient maintenance, and aesthetic appreciation value [5,6,8-10]. Constructed wetlands have a good removal effect on turbidity, $\mathrm{COD}, \mathrm{TP}, \mathrm{NH}_{4}{ }^{+}-\mathrm{N}$, and several other pollutants, but not a satisfying removal effect on $\mathrm{NO}_{3}{ }^{-}-\mathrm{N}$, difficult to live up to nitrogen standard especially when treating wastewater devoid of organic carbon to offer electrons [11,12].

Therefore, some research has been conducted to enhance denitrification in constructed wetlands to treat wastewater with low $\mathrm{C} / \mathrm{N}$ ratio, which mainly include adding external carbon sources [13-15], incorporating autotrophic denitrification into constructed wetlands [16-18] and alternative strengthening methods such as micro aeration $[19,20]$. For wastewater with insufficient carbon source, when heterotrophic denitrification is applied, acetic acid, formic acid, ethanol, or other substances able to provide carbon source are required to be added into the water, which have a high cost and may cause secondary pollution [21]. However, sulfur autotrophic denitrification, as one kind of autotrophic denitrification technologies, can utilize reductive sulfur such as $\mathrm{S}^{2-}, \mathrm{S}^{0}$, and $\mathrm{S}_{2} \mathrm{O}_{3}{ }^{2-}$ as energy source and electron donor, and use nitrate as electron acceptor to accomplish denitrification [22-25]. Due to the advantages of needing no external organic carbon source, high removal performance in nitrogen pollutants, economic feasibility, more sustainability, and distinct reduction in nitrous oxide emissions [26-28], sulfur autotrophic denitrification has been gradually paid more attention in recent years. Currently, even though related research on surface water and groundwater are available, studies on advanced treatment and resource recycling of steel wastewater with low $\mathrm{C} / \mathrm{N}$ ratio and complex composition by incorporating sulfur autotrophic denitrification technology into constructed wetlands are still few, with its feasibility unexplored.

Therefore, in this study, a constructed wetland system combining sulfur autotrophic denitrification was built to explore the feasibility of applying sulfur autotrophic denitrification to advanced denitrification of steel industry wastewater, especially steel rolling wastewater. Through the monitoring of various pollutants including different forms of nitrogen pollutants, as well as the characterization of fillers and microbial community identification, the study tries to illustrate the efficiency and pathways of nitrogen removal in the system, providing technical support and experience in efficient denitrification of steel wastewater.

\section{Materials and Methods}

\subsection{Materials and Reactor}

The reactor ( $\mathrm{L} 1.5 \mathrm{~m} \times \mathrm{W} 0.8 \mathrm{~m} \times \mathrm{H} 0.8 \mathrm{~m}$ ), as shown in Figure 1, was made of a PVC plate to simulate the constructed horizontal subsurface flow wetland. The composite constructed wetland consists of two sections. The first section is filled with ceramsite (5-15 mm), called $\mathrm{HF}_{\mathrm{C}}$. The second section is filled with evenly mixed fillers made of $6 / 10$ ceramic particles $(5-15 \mathrm{~mm}), 3 / 10$ sulfur $(2-5 \mathrm{~mm})$, and $1 / 10$ lime, called $\mathrm{HF}_{\mathrm{SAD}}$. The volume ratio of $\mathrm{HF}_{\mathrm{C}}$ to $\mathrm{HF}_{\mathrm{SAD}}$ is $4: 1$. The surface of the subsurface flow constructed wetland is covered with soil ( $5 \mathrm{~cm}$ thick). Reeds are planted on the soil with a density of around 50 plants $/ \mathrm{m}^{2}$.

In order to shorten the cultivation and domestication time of microorganisms, the sludge in the natural water body containing substantial and various microorganisms was inoculated into the reactor. The inoculated sludge was taken from sedimentary sediment of a river in campus (Sanhaowu Lake in Tongi University, Shanghai, China at $31^{\circ} 17^{\prime} 27.36^{\prime \prime}$ $\mathrm{N}$ latitude and $121^{\circ} 30^{\prime} 35.40^{\prime \prime} \mathrm{E}$ longitude), which had high biological activity. $300 \mathrm{~mL}$ of sludge was diluted to $1800 \mathrm{~mL}$ and was placed in for acclimation culture. After cultivating the sludge for one week, it was inoculated into the reactor. In order to ensure the even inoculation of sludge, the mixed sludge inoculation liquid was separated and added into 
the experimental reactor during filling of the mixed filler into the reactor several times, ensuring that the filler and sludge were fully mixed and the amount of inoculated sludge in the reactor was evenly distributed. The sludge was cultivated in the reactor, and a certain amount of microorganisms were fixed by the physical interception and adsorption of the filler, the attraction of the negative charge on the surface of the microorganisms and the positive charge on the surface of the filter material, and the adhesion of the microbial metabolites. The microorganisms grew and multiplied continuously on the reactor packing, and finally formed a biofilm with a certain thickness. After that, the normal operation and monitoring was started.

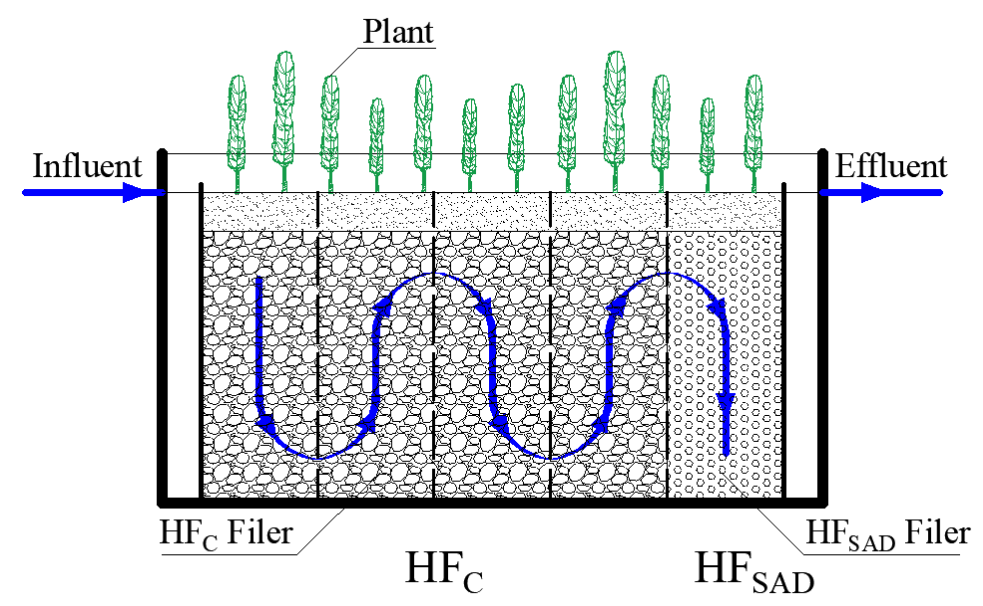

Figure 1. Reactor which combined $\mathrm{HF}_{\mathrm{C}}$ and $\mathrm{HF}_{\mathrm{SAD}}$.

The reactor was operated for three months during its normal operation period (not including the acclimation period). During its operation period, the reactor was run in the following three conditions in turn: (1) $\mathrm{HRT}_{\mathrm{C}}=2 \mathrm{~d}, \mathrm{HRT}_{\mathrm{SAD}}=0.5 \mathrm{~d} ;(2) \mathrm{HRT}_{\mathrm{C}}=4 \mathrm{~d}$, $\mathrm{HRT}_{\mathrm{SAD}}=1 \mathrm{~d}$; (3) $\mathrm{HRT}_{\mathrm{C}}=6 \mathrm{~d}, \mathrm{HRT}_{\mathrm{SAD}}=1.5 \mathrm{~d}$. Each condition was run for a month.

Realistic treated steel rolling wastewater was adopted as the influent of the reactor. The concentrations of different pollutants and corresponding recycling standard are shown in Table 1. The recycling standard is formulated based on The Reuse of Urban Recycling Water-Water Quality Standard for Industrial Uses (GB/T19923-2005) and the requirements of steel enterprises for the recycled water.

Table 1. Characteristics of steel rolling wastewater.

\begin{tabular}{|c|c|c|c|c|c|c|}
\hline Index & $\mathrm{pH}$ & Turbidity & $\begin{array}{c}\mathrm{COD}_{\mathrm{Cr}} \\
\left(\mathrm{O}_{2}, \mathrm{mg} \cdot \mathrm{L}^{-1}\right)\end{array}$ & $\begin{array}{c}\mathrm{TP} \\
\left(\mathrm{mg} \cdot \mathrm{L}^{-1}\right)\end{array}$ & $\begin{array}{c}\mathrm{TN} \\
\left(\mathrm{mg} \cdot \mathrm{L}^{-1}\right)\end{array}$ & $\mathrm{C} / \mathrm{N}$ \\
\hline Range & $6.0-9.3$ & $6.97-9.82$ & $32.9-42.6$ & $0.19-0.49$ & $7.38-9.90$ & $3.5-5.3$ \\
\hline Average & 7.6 & 8.38 & 37.9 & 0.34 & 9.01 & 4.2 \\
\hline $\begin{array}{l}\text { Recycling } \\
\text { Standard }\end{array}$ & $7-8$ & $\leq 5$ & $\leq 30$ & $\leq 0.8$ & $\leq 5$ & - \\
\hline
\end{tabular}

\subsection{Analytical Methods}

Water samples were routinely collected every three days, from the influent, the end of $\mathrm{HF}_{C}$, and the end of $\mathrm{HF}_{\mathrm{SAD}}$. All samples were filtered through disposable Millipore filters $(0.22 \mu \mathrm{m}$ pore size) before either being analyzed immediately or stored in a refrigerator at $4{ }^{\circ} \mathrm{C}$ until the analyses were performed. Sample analysis was carried out less than $24 \mathrm{~h}$ after sample collection. Samples were analyzed for $\mathrm{COD}, \mathrm{NH}_{4}{ }^{+}-\mathrm{N}, \mathrm{NO}_{3}{ }^{-}-\mathrm{N}, \mathrm{TN}$, and TP concentrations using standard methods, with DRB200 and DR3900 (HACH, Loveland, CO, USA). Dissolved oxygen and $\mathrm{pH}$ were monitored using a Hach HQ30D portable multi meter, and the turbidity was analyzed with Hach 2100Q Portable Turbidimeter (HACH, USA). 
The surface properties of the fillers were studied through scanning electron microscopy (SEM). In order to investigate the principle of sulfur autotrophic denitrification, the microbial community sampling was carried out after the operation of the experimental reactor was stabilized. Sludge from the front of $\mathrm{HF}_{\mathrm{C}}$, the end of $\mathrm{HF}_{\mathrm{C}}$, and the $\mathrm{HF}_{\mathrm{SAD}}$ in the reactor was collected into sterile centrifuge tubes and stored in a refrigerator at $-80^{\circ} \mathrm{C}$. The microbial community identification was conducted by Shanghai Meiji Biomedical Technology Co., Ltd. (Shanghai, China).

\section{Results and Discussions}

\subsection{Treatment Effect of Contaminants}

The composite constructed wetland reactor was operated continuously for over three months in three kinds of operation conditions in turn, and the concentrations of different contaminants in the influent and effluent were monitored and analyzed, as shown in Table 2.

Table 2. Treatment effect of composite constructed wetlands.

\begin{tabular}{|c|c|c|c|c|c|c|}
\hline Index & $C_{\text {in }}\left(\mathrm{mg} \cdot \mathrm{L}^{-1}\right)$ & $\mathrm{C}_{\mathrm{C}}\left(\mathrm{mg} \cdot \mathrm{L}^{-1}\right)$ & $\mathrm{C}_{\mathrm{SAD}}\left(\mathrm{mg} \cdot \mathrm{L}^{-1}\right)$ & $\mathrm{RE}_{\mathrm{C}}$ & $\mathrm{RE}_{\text {SAD }}$ & TRE \\
\hline Turbidity & $\begin{array}{c}8.43 \\
(6.97-9.95)\end{array}$ & 0.71 & 0.55 & $91.5 \%$ & $15.2 \%$ & $93.5 \%$ \\
\hline $\mathrm{pH}$ & $\begin{array}{c}7.15 \\
(7.04-7.30)\end{array}$ & 7.11 & 6.85 & - & - & - \\
\hline DO & $\begin{array}{c}3.6 \\
(3.2-4.1)\end{array}$ & 3.1 & 0.4 & $13.9 \%$ & $86.1 \%$ & $88.0 \%$ \\
\hline $\mathrm{TP}$ & $\begin{array}{c}0.33 \\
(0.22-0.53)\end{array}$ & 0.10 & 0.05 & $65.5 \%$ & $45.1 \%$ & $81.3 \%$ \\
\hline COD & $\begin{array}{c}39.1 \\
(32.6-56.2)\end{array}$ & 17.7 & 14.9 & $53.9 \%$ & $15.5 \%$ & $61.4 \%$ \\
\hline $\mathrm{NH}_{4}^{+}-\mathrm{N}$ & $\begin{array}{c}4.12 \\
(2.99-5.54)\end{array}$ & 2.06 & 1.75 & $50.2 \%$ & $16.3 \%$ & $58.6 \%$ \\
\hline $\mathrm{NO}_{3}{ }^{-}-\mathrm{N}$ & $\begin{array}{c}3.14 \\
(2.07-4.39)\end{array}$ & 4.34 & 1.57 & $-42.9 \%$ & $64.1 \%$ & $47.4 \%$ \\
\hline Organic nitrogen & $\begin{array}{c}1.83 \\
(1.27-2.78)\end{array}$ & 0.31 & 0.60 & $81.9 \%$ & $-63.4 \%$ & $74.0 \%$ \\
\hline $\mathrm{TN}$ & $\begin{array}{c}9.07 \\
(7.38-10.19)\end{array}$ & 6.72 & 3.75 & $25.6 \%$ & $45.6 \%$ & $58.6 \%$ \\
\hline
\end{tabular}

Note: a. $C_{i n}, C_{C}$, and $C_{S A D}$ represent the concentration in influent, effluent of $H F_{C}$, and effluent of $H F_{S A D}$, respectively. $b$. $R E_{C}$, $R E_{S A D}$, and TRE represent the removal efficiency of $\mathrm{HF}_{C}, \mathrm{HF}_{\mathrm{SAD}}$, and the whole reactor, respectively. c. Organic nitrogen was monitored to analyze the transformation pathway of nitrogen in the whole reactor.

The results showed that high removal efficiency of turbidity, TP, and COD was achieved, with the concentration meeting the reuse standard very well. $\mathrm{pH}$, an important environmental factor which can influence the growth of microorganisms and plants, were stabilized to a normal range in $\mathrm{HF}_{\mathrm{C}}$. The slight decrease of $\mathrm{pH}$ in $\mathrm{HF}_{\mathrm{SAD}}$ can attribute to the production of $\mathrm{H}^{+}$during the reaction of sulfur autotrophic denitrification.

The oxygen absorbed by plants in $\mathrm{HF}_{\mathrm{C}}$ supplemented oxygen into the substrate, which made $\mathrm{DO}$ in $\mathrm{HF}_{\mathrm{C}}$ maintain a relatively high level. However, the filter especially like sulfur hindered the downward growth of plant roots in $\mathrm{HF}_{\mathrm{SAD}}$ so that the roots could just grow in shallow soil areas, which made supplementation of DO difficult in deep areas in $\mathrm{HF}_{\mathrm{SAD}}$. $\mathrm{DO}$ was quickly consumed in the front part of $\mathrm{HF}_{\mathrm{SAD}}$, leading to the facultative anaerobic condition and low dissolved oxygen concentration in effluent. The facultative anaerobic condition was vital for the utilization of sulfur and sulfur autotrophic denitrification.

$\mathrm{COD}$ was removed greatly after treatment in $\mathrm{HF}_{\mathrm{C}}$ with an average removal efficiency of $53.9 \%$, and the removal efficiency of COD was enhanced with the increase of HRT. When HRT $_{C}$ increased from $4 \mathrm{~d}$ to $6 \mathrm{~d}$, the removal efficiency of COD was not as good as that when $\mathrm{HRT}_{\mathrm{C}}$ from $2 \mathrm{~d}$ to $4 \mathrm{~d}$. The COD removal ratio of $\mathrm{HF}_{\mathrm{SAD}}$ was lower under three HRT conditions, due to the decrease of COD to the lower range $\left(<20 \mathrm{mg} \cdot \mathrm{L}^{-1}\right)$. The residual 
COD biodegradability was poor, and the water-soluble trace $\mathrm{S}$ may also be included in COD. Even though there existed differences in the composition of wastewater, the removal performance of $\mathrm{HF}_{\mathrm{C}}$ in this study was similar to many studies, such as the studies of $\mathrm{Xu}$ et al. [29] and Schulz et al. [30]. The concentrations of COD and some other regular pollutants could meet the reuse standard just after treatment in $\mathrm{HF}_{\mathrm{C}}$, but nitrogen pollutants hindered the compliance to related criteria of wastewater, rendering the need of further efficient denitrification.

\subsection{The TN Variation and Its Removal Efficiency}

The convention and removal efficiency in different points in the reactor are shown in Figure 2. The concentration of TN in the influent of the reactor ranged from $7.38 \mathrm{mg} \cdot \mathrm{L}^{-1}$ to $10.91 \mathrm{mg} \cdot \mathrm{L}^{-1}$, with the mean of $9.07 \mathrm{mg} \cdot \mathrm{L}^{-1}$ and standard deviation of 0.61 . When HRT $_{C}$ was $2 \mathrm{~d}$ and HRT $\mathrm{HAD}_{\mathrm{S}}$ was $0.5 \mathrm{~d}$, the average removal percentage of TN in $\mathrm{HF}_{\mathrm{C}}$ was $16.8 \%$, and the average concentration of $\mathrm{TN}^{\text {in }} \mathrm{HF}_{\mathrm{C}}$ effluent was reduced to $7.59 \mathrm{mg} / \mathrm{L}$. The average concentration of $\mathrm{TN}$ in the effluent of $\mathrm{HF}_{\mathrm{SAD}}$ was $5.41 \mathrm{mg} \cdot \mathrm{L}^{-1}$, with the removal efficiency of $28.4 \%$ in $\mathrm{HF}_{\mathrm{SAD}}$ and the removal efficiency of $40.5 \%$ in the whole reactor. When HRT $_{C}$ was $4 \mathrm{~d}$ and $\mathrm{HRT}_{\mathrm{SAD}}$ was $1 \mathrm{~d}$, the average removal efficiency of $\mathrm{HF}_{\mathrm{C}}$ was $24.1 \%$, and the average TN concentration of $\mathrm{HF}_{\mathrm{C}}$ effluent was reduced to $6.76 \mathrm{mg} \cdot \mathrm{L}^{-1}$. The average concentration of $\mathrm{TN}$ in the effluent of $\mathrm{HF}_{\mathrm{SAD}}$ was $3.66 \mathrm{mg} \cdot \mathrm{L}^{-1}$, with the removal efficiency of $45.8 \%$ compared with the average $\mathrm{TN}$ concentration of $\mathrm{HF}_{\mathrm{SAD}}$ influent and the removal efficiency of $59.0 \%$ in the whole reactor. When $\mathrm{HRT}_{\mathrm{C}}$ was $6 \mathrm{~d}$ and $\mathrm{HRT}_{\mathrm{SAD}}$ was $1.5 \mathrm{~d}$, the average removal efficiency of $\mathrm{HF}_{\mathrm{C}}$ was $35.9 \%$, and the average $\mathrm{TN}$ concentration of $\mathrm{HF}_{\mathrm{C}}$ effluent was reduced to $5.81 \mathrm{mg} \cdot \mathrm{L}^{-1}$. The average concentration of TN in the effluent of $\mathrm{HF}_{\mathrm{SAD}}$ was $2.18 \mathrm{mg} \cdot \mathrm{L}^{-1}$, with a removal efficiency of $62.6 \%$ in $\mathrm{HF}_{\mathrm{SAD}}$ and a total removal efficiency of $76.3 \%$ in the whole reactor.

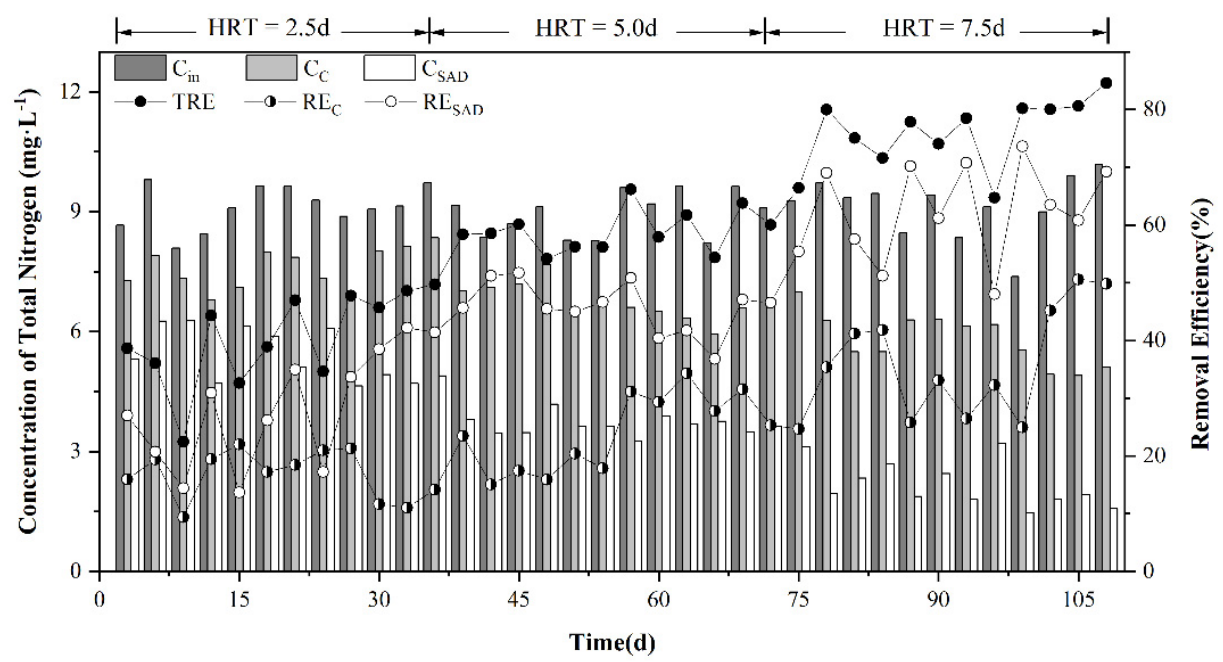

Figure 2. The concentration variation of total nitrogen.

It was obvious that the removal efficiency of $\mathrm{TN}$ in $\mathrm{HF}_{\mathrm{C}}$ and $\mathrm{HF}_{\mathrm{SAD}}$ raised with $\mathrm{HRT}$ increasing, and the removal efficiency of $\mathrm{TN}$ in $\mathrm{HF}_{\mathrm{SAD}}$ was larger than in $\mathrm{HF}_{\mathrm{C}}$. When $\mathrm{HRT}_{\mathrm{C}}$ was as long as 6 days or more, TN concentration of effluent in $\mathrm{HF}_{\mathrm{C}}$ was able to meet the water quality standard for reuse. Therefore, it was hard to meet the standard by only using $\mathrm{HF}_{\mathrm{C}}$ on the condition of short HRT, while longer HRT would reduce the treatment flow and capacity of constructed wetlands. Combined with $\mathrm{HF}_{\mathrm{SAD}}$, CWs could perform better on denitrification and accomplish all treatment requirements perfectly and efficiently.

Torrijos et al. [31] utilized a combined system of vertical-flow constructed wetland and horizontal-flow constructed wetland to treat industrial wastewater, with a TN removal efficiency of less than $50 \%$ and a low flux of $0.6-1.2 \mathrm{~g} \mathrm{TN} \cdot \mathrm{m}^{-2} \cdot \mathrm{d}^{-1}$. Masi et al. [32] constructed a wetland where $\mathrm{TN}$ concentration was $8.5 \mathrm{mg} \cdot \mathrm{L}^{-1}$ and $\mathrm{NO}_{3}{ }^{-}-\mathrm{N}$ concentration 
was $5.5 \mathrm{mg} / \mathrm{L}$, similar to this study. During the first three years of Masi's experiment, the removal efficiency of $\mathrm{NO}_{3}{ }^{-}-\mathrm{N}$ was $50 \%$ and $\mathrm{TN}$ removal efficiency was 30\%. The removal efficiency of their studies was similar to $\mathrm{HF}_{\mathrm{C}}$ in this study, which indicated that it was hard for conventional constructed wetlands to achieve relatively high nitrogen removal efficiency. However, $\mathrm{HF}_{\mathrm{SAD}}$ had a good performance on removing total nitrogen, with larger removal efficiency of $\mathrm{TN}$ than that in $\mathrm{HF}_{\mathrm{C}}$, which finally contributed to meeting the recycling standard for $\mathrm{TN}$.

\subsection{Transformation of Nitrogen Contaminants}

Different forms of nitrogen pollutants including $\mathrm{NH}_{4}{ }^{+}-\mathrm{N}, \mathrm{NO}_{3}{ }^{-}-\mathrm{N}, \mathrm{ON}$, and $\mathrm{TN}$ in the influent and effluent of two HFs were monitored and analyzed, as shown in Figure 3.

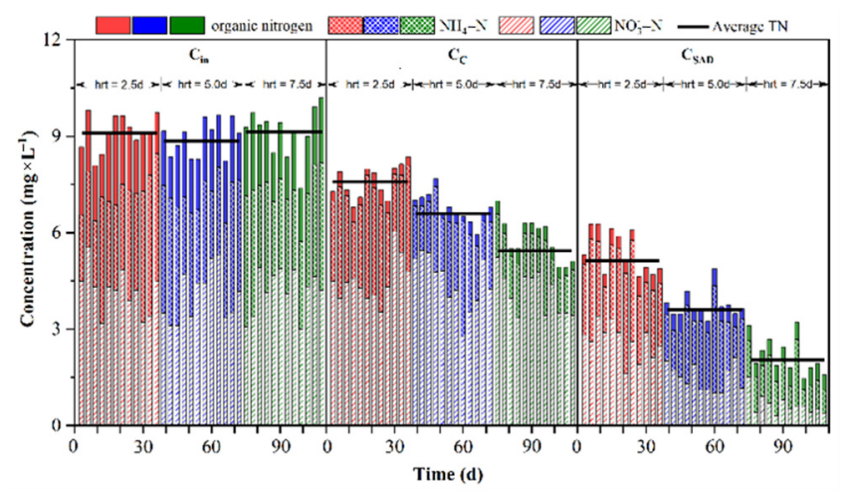

Figure 3. The concentrations of different types of nitrogen contaminants.

Since the wastewater influent had already been preliminarily treated, concentration of various nitrogen contaminants and $\mathrm{TN}$ were relatively stable and basically in the same level under three HRT conditions. In $\mathrm{HF}_{\mathrm{C}}$, there existed three processes, ammonification of organic nitrogen, nitrification, and denitrification. Organic nitrogen was converted to ammonia by ammonification, with an average removal efficiency of $81.9 \%$, which resulted in the concentration of ammonia to be ammonized of $5.61 \mathrm{mg} \cdot \mathrm{L}^{-1}$. The apparent removal efficiency of ammonia was $50.2 \%$, and the net removal efficiency was $63.3 \%$. The concentration of nitrate in effluent was higher than that in influent, but considering the conversion of ammonia into nitrate, the initial net concentration of nitrate was $6.85 \mathrm{mg} / \mathrm{L}$, while the net removal efficiency of nitrate was 35.1\% through denitrification.

There was an anaerobic environment in $\mathrm{HF}_{\mathrm{SAD}}$ and the concentration of organic nitrogen in influent was low, so it was basically not removed. Remaining DO at the front part of HF $_{\mathrm{SAD}}$ and the oxygen absorbed by plants roots in the shallow soil area contributed to the local aerobic environment, which caused the occurrence of nitrification. The average removal efficiency of ammonia was $16.3 \%$ in $\mathrm{HF}_{\mathrm{SAD}}$, and the maximum removal efficiency of $23.9 \%$ was achieved when HRT $_{S A D}$ was $1.5 \mathrm{~d}$. Denitrification occurred in the main part of $\mathrm{HF}_{\mathrm{SAD}}$, which was due to the average removal efficiency of nitrate of $64.1 \%$. The concentration of organic nitrogen in effluent of $\mathrm{HF}_{\mathrm{SAD}}$ was slightly higher than that in influent, which may be attributable to the weak ammonification and the assimilation of inorganic nitrogen into organic nitrogen in microorganisms.

The operational effects of $\mathrm{HF}_{\mathrm{C}}$ and $\mathrm{HF}_{\mathrm{SAD}}$ were analyzed to find out their removal rates for different types of nitrogen contaminants (the amount of contaminants removed per unit time and area), which is shown in Figure 4. The analysis indicated that the removal rates of nitrogen contaminants (if it was negative, the absolute value was considered, indicating the degree of increase) decreased with increasing HRT. As HRT increased, the removal amount of nitrogen contaminants increased, but its degree was not as high as that of HRT, which contributed to the decreasing trend of ratio. Relatively strong nitrification and weak denitrification meant that the concentration of nitrate in effluent was higher than that in influent in $\mathrm{HF}_{\mathrm{C}}$, which was contrary to that in $\mathrm{HF}_{\mathrm{SAD}}$. The removal capacity 
of nitrate was positive in $\mathrm{HF}_{\mathrm{C}}$ and negative in $\mathrm{HF}_{\mathrm{SAD}}$, but the decreasing degree of their absolute was different. Therefore, from the perspective of the whole reactor, the removal capacity of nitrate increased with the increasing of HRT.

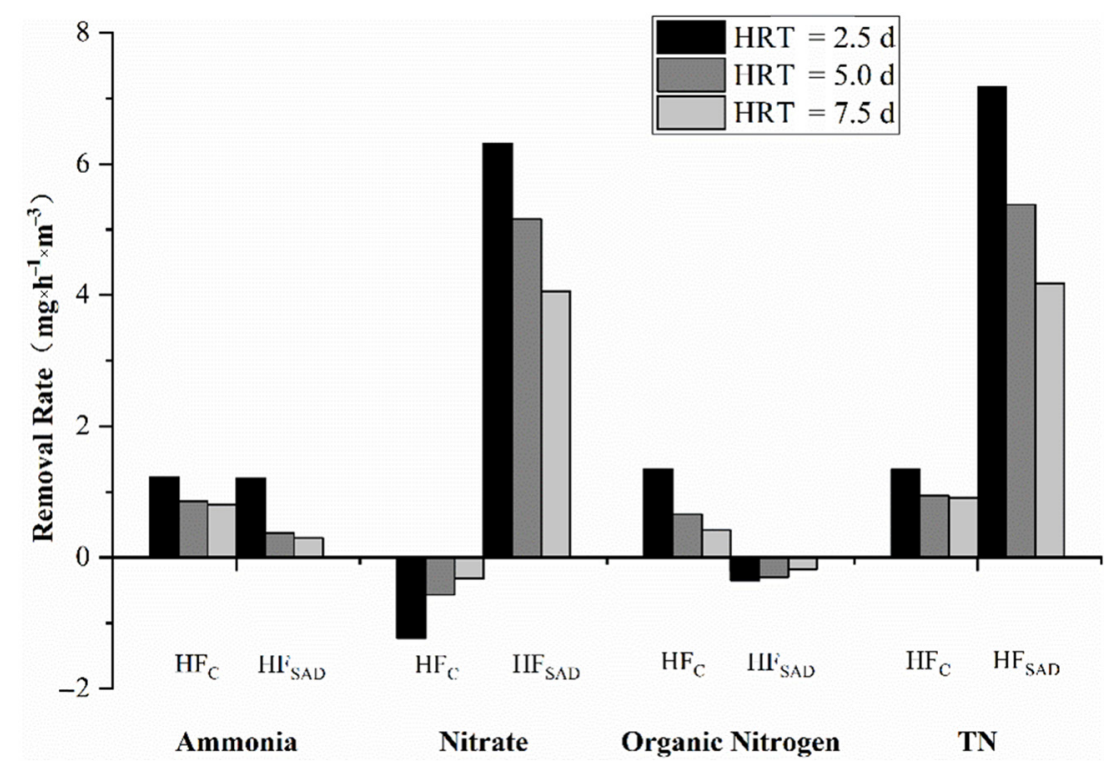

Figure 4. Removal rates of nitrogen contaminants.

The removal efficiency of ammonia in $\mathrm{HF}_{\mathrm{C}}$ was greater than that in $\mathrm{HF}_{\mathrm{SAD}}$ under the condition of the same HRT, which was more obvious when HRT was longer. Even though produced nitrate by nitrification was considered, the removal efficiency of nitrate in $\mathrm{HF}_{\mathrm{C}}$ was still less than that in $\mathrm{HF}_{\mathrm{SAD}}$, which was similar to the conclusion that the net removal efficiency of nitrate in $\mathrm{HF}_{\mathrm{C}}$ was only approximately half of that in $\mathrm{HF}_{\mathrm{SAD}}$. The removal efficiency of $\mathrm{TN}$ could be considered as the comprehensive performance of removing these three forms of nitrogen contaminants. Under different HRT conditions, the removal efficiency of TN in $\mathrm{HF}_{\mathrm{SAD}}$ was about 3-5 times higher than that in $\mathrm{HF}_{\mathrm{C}}$, which confirmed that combining with sulfur autotrophic denitrification technology in constructed wetlands had a very good feasibility in nitrogen removal.

\subsection{Analysis of Nitrogen Removal Pathway}

In constructed wetlands, the removal of nitrogen contaminants mainly depends on the adsorption of substrate and plants, microbial denitrification, and volatilization. Nitrogen contaminants in pre-treated steel rolling wastewater are mainly ammonia and nitrate and a small amount of organic nitrogen. In this study, the internal microenvironment was different in conventional constructed wetlands and wetlands enhanced with sulfur autotrophic denitrification technology. The concentration of $\mathrm{DO}$ in $\mathrm{HF}_{\mathrm{C}}$ was relatively higher, and plants with well-developed roots could carry out oxygen transfer and supplement internal DO to maintain the environment with high DO concentration, which contributed to strong nitrification occurring inside $\mathrm{HF}_{\mathrm{C}}$. In $\mathrm{HF}_{\mathrm{SAD}}$, $\mathrm{DO}$ was insufficient in the front part and then consumed rapidly, which contributed to the internal anaerobic environment. The concentration of DO in the effluent of $\mathrm{HF}_{\mathrm{SAD}}$ was $0.2-0.7 \mathrm{mg} / \mathrm{L}$ with the mean of $0.4 \mathrm{mg} / \mathrm{L}$, resulting in the growth of facultative and anaerobic bacteria, thereby facilitating the occurrence of sulfur autotrophic denitrification reaction.

The main pathways to remove nitrogen are nitrification and subsequent denitrification [33]. Alternate coexistence of aerobic microenvironment and local anoxic environment contributed to the ammonification of organic nitrogen and nitrification of ammonia, as well as denitrification in $\mathrm{HF}_{\mathrm{C}}$. Low concentration and rapid consumption of $\mathrm{DO}$ in $\mathrm{HF}_{\mathrm{SAD}}$ and the insufficient carbon source in wastewater with the $\mathrm{C} / \mathrm{N}$ ratio of 2.6 impeded the occurrence of heterotrophic denitrification. Therefore, the high removal performance of 
nitrate and corresponding $\mathrm{TN}$ in $\mathrm{HF}_{\mathrm{SAD}}$ was attributed to the autotrophic denitrification. Combined with the monitored $\mathrm{SO}_{4}{ }^{2-}$ in effluent, microbial identification analysis, and previous conducted and published research, it can be concluded that sulfur autotrophic denitrification occurred in $\mathrm{HF}_{\mathrm{SAD}}$. $\mathrm{S}$ acted as electron donor to provide electrons, and nitrate acted as electron acceptor, with the following reaction occurring as Equation (1) [18,34] The reaction also explained the small increase of the concentration of organic nitrogen in $\mathrm{HF}_{\mathrm{SAD}}$.

$$
\mathrm{NO}_{3}{ }^{-}+1.1 \mathrm{~S}+0.4 \mathrm{CO}_{2}+0.76 \mathrm{H}_{2} \mathrm{O}+0.08 \mathrm{HCO}_{3}{ }^{-}+0.08 \mathrm{NH}_{4}{ }^{+} \rightarrow 0.08 \mathrm{C}_{5} \mathrm{H}_{7} \mathrm{O}_{2} \mathrm{~N}+0.5 \mathrm{~N}_{2}+1.1 \mathrm{SO}_{4}{ }^{2-}+1.28 \mathrm{H}^{+}
$$

Combining with previous research and this study, the transformation and removal pathway of nitrogen contaminants in the two constructed wetlands can be summarized and concluded as shown in Figure 5.
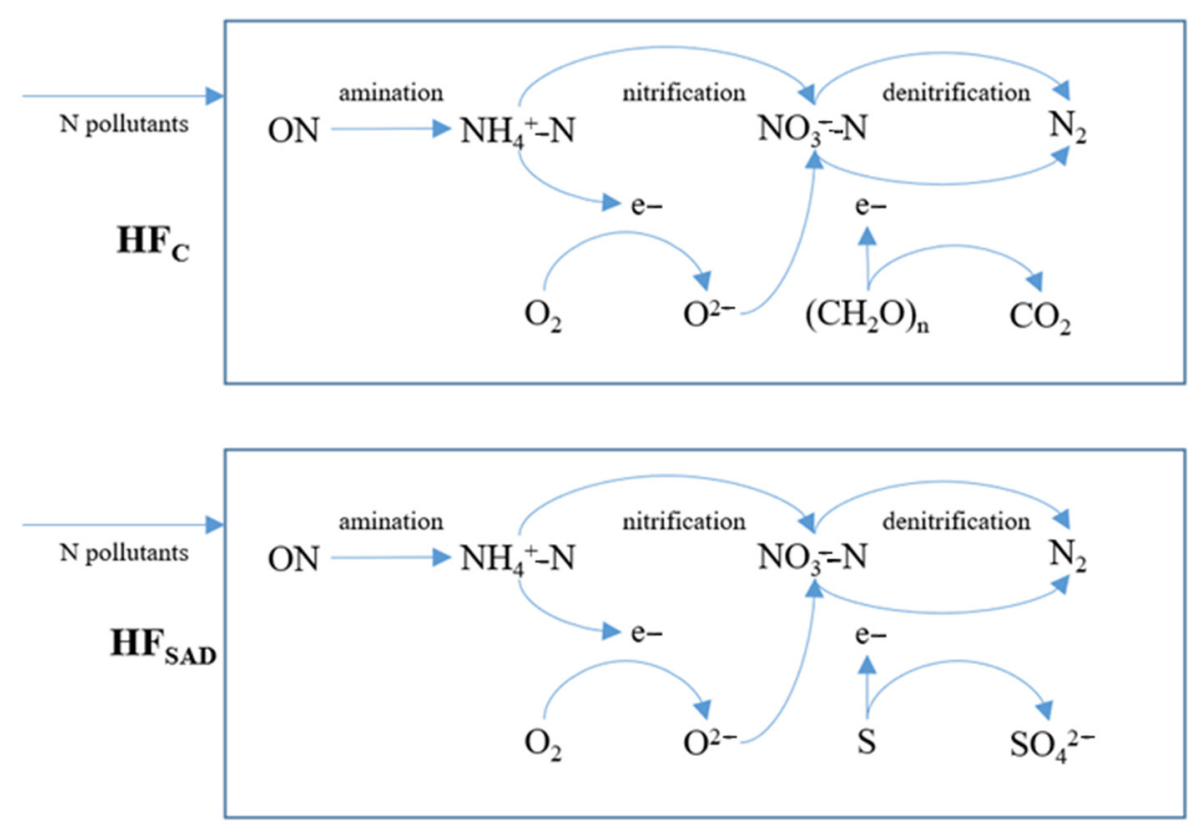

Figure 5. Transformation and removal pathways in $\mathrm{HF}_{\mathrm{C}}$ and $\mathrm{HF}_{\mathrm{SAD}}$.

\subsection{Microbial Community Structure}

The analysis of community structure was carried out at the genus level, with the result shown in Figure 6. Microorganism whose content was more than 3\% in the level of strains mainly included Thiobacillus, Rhodocyclaceae, Anaerolineaceae, Sulfuritalea, Sulfurimonas, Hydrogenophilaceae, and Denitratisoma.

Thiobacillus, a kind of autotrophic denitrifying bacteria, was the dominant species in the system, which can use elemental sulfur and inorganic carbon sources as its energy source when they grow in a mixed environment $[35,36]$. Rhodocyclaceae, a kind of anaerobic bacterium, was widely distributed in activated sludge. Rhodocyclaceae was brought into the $\mathrm{HF}_{\mathrm{SAD}}$ system with sludge inoculation in the early stage, and its content decreased with the operation of the reactor. In the sulfur-containing system, the dominant species gradually decline, and sulfur autotrophic bacteria gradually occupied the dominant position in activated sludge $[37,38]$. 


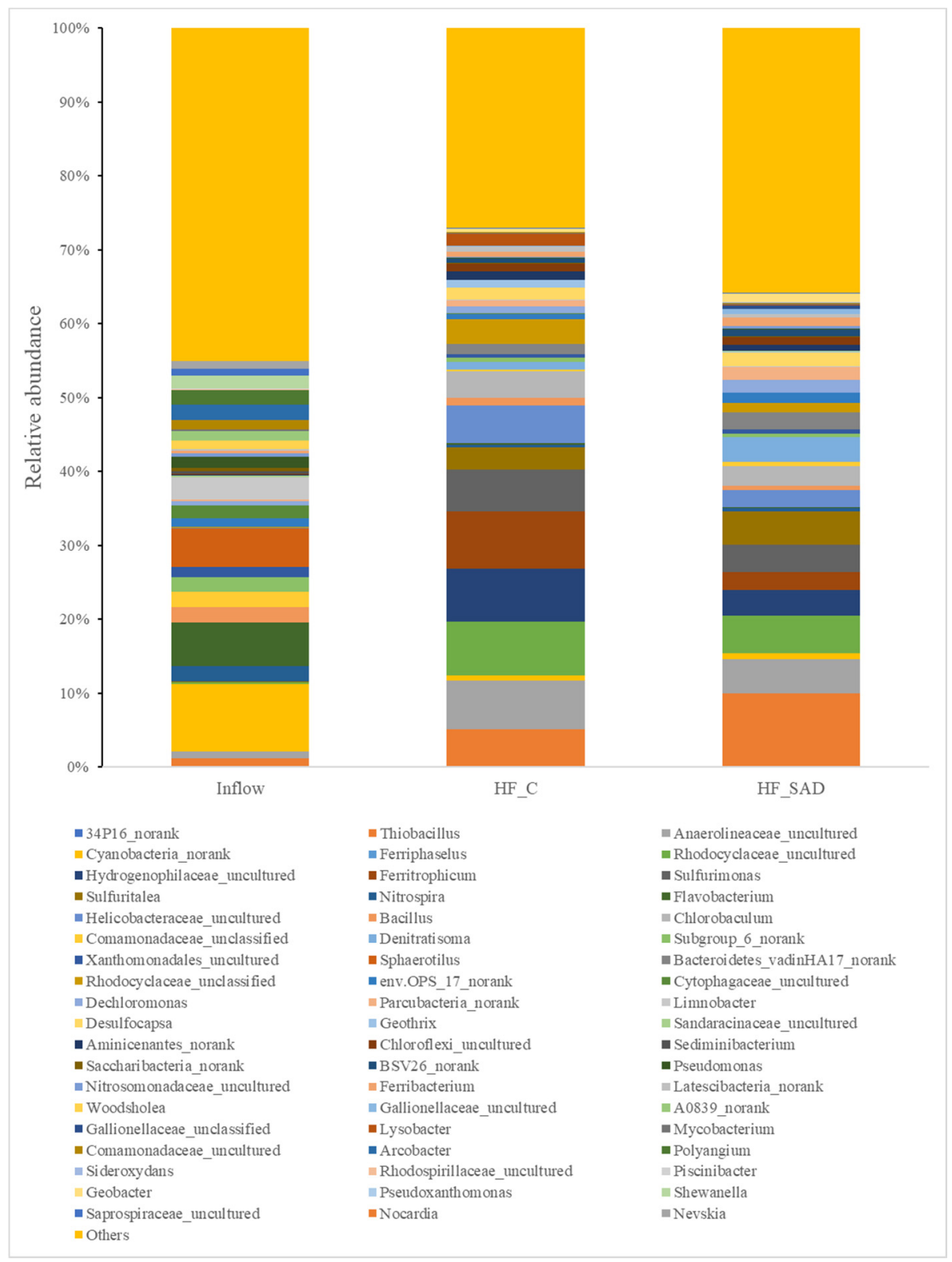

Figure 6. Components in genus level of microbial community.

Sulfuritalea is a novel facultative autotrophic bacterium that grows as a sole electron donor with thiosulfate, elemental sulfur, and hydrogen as the sole electron donor, and is able to utilize nitrate as an electron acceptor [39]. Sulfurimonas, a kind of facultative anaerobic and autotrophic bacteria, is the most conventional bacterium in the sulfur autotrophic denitrification system, which mainly uses hydrogen, sulfur element, and sulfide as energy, $\mathrm{CO}_{2}$ as a carbon source, and nitrate or ammonium salt as a nitrogen source of chemical energy. Hydrogenophilaceae bacteria are a class of strictly autotrophic, aerobic, or facultative anaerobic sulfur-oxidizing bacteria [40,41], widely distributed in wastewater treatment systems and occupying a higher abundance [42,43], being major contributors to the utilization of sulfur in the system. Denitratisoma is a widespread denitrifying bacterium in municipal sludge [44]. Denitrifying bacteria were dominant in the reactor, with a satisfying denitrification effect [44]. Thiobacillus, Sulfuritalea, and Sulfurimonas had higher abundance in the sulfur autotrophic denitrifying system than those of the ceramsite system, while the traditional dominant denitrification bacteria, Rhodocyclaceae and Rhodocyclaceae, were replaced by ulfur autotrophic denitrifying 
bacteria, which indicated that the autotrophic denitrification process took place in the experimental reactor, and the effect was obvious.

According to previous studies $[45,46]$, Thiobacillus and Sulfurimonas are usually the most conventional autotrophic denitrifying bacteria, which can reduce nitrate to $\mathrm{N}_{2}$ and oxidize S or reduced sulfide to sulfate. Thiobacillus (51.4-58.6\%), Sulfurimonas (18.9-20.7\%), and Ignavibacteriales (18.9-20.7\%) were the dominant species in the sulfur autotrophic denitrification system studied by Zhang et al. [47]. Most of these studies were carried out in relatively pure culture medium or reactor, consequently where bacteria were relatively pure. In this study, the constructed wetland had a complex environment and abundant microbial species, so the species of bacteria were more abundant than those in other studies, but the species of dominant bacteria were basically consistent with their findings.

\subsection{Characterization of Filler}

In order to analyze the effect of filler surface characteristics on the reaction, ceramsite, limestone, and granular sulfur were observed by scanning electron microscopy (SEM), as shown in Figure 7. There were substantial tiny pores on the surface of the ceramsite, and the porous structure had a large specific surface area. The structure of limestone was mainly lamellar structure and there were also many pores on the surface. Granular sulfur had a layer structure formed by the aggregation of innumerable particles of very small particle size, with regular particles having a particle size of about $300 \mathrm{~nm}$.

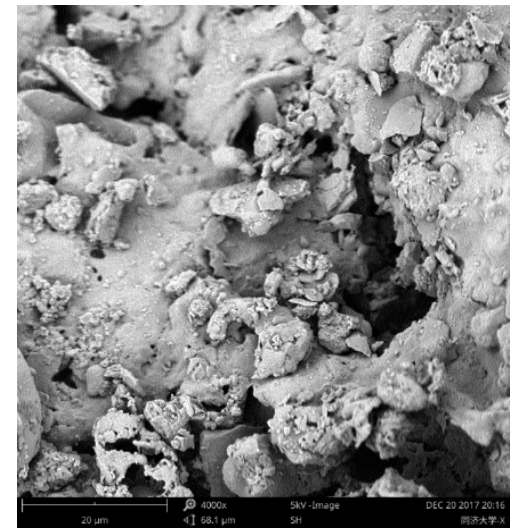

(a) Ceramsite before reaction

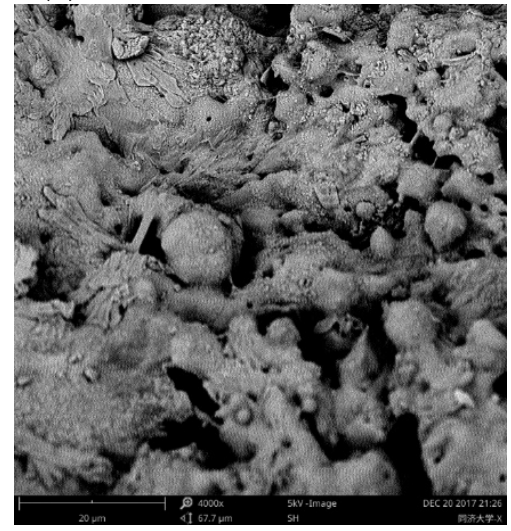

(d) Ceramsite after reaction

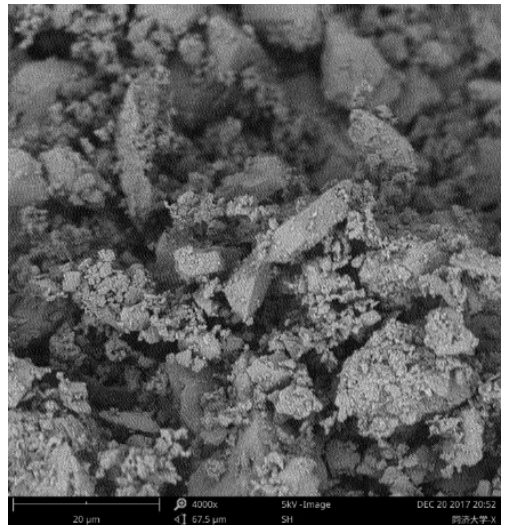

(b) Limestone before reaction

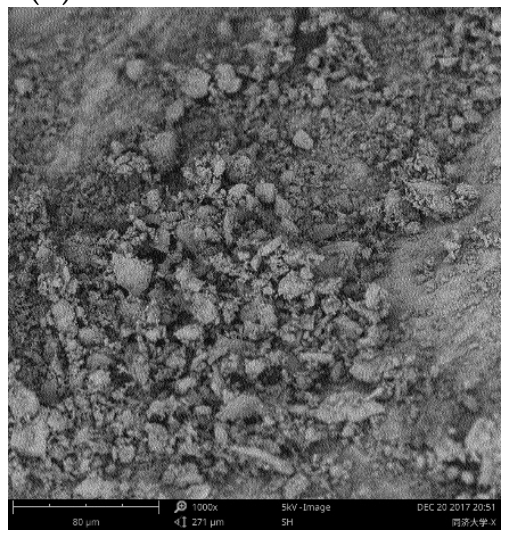

(e) Limestone after reaction

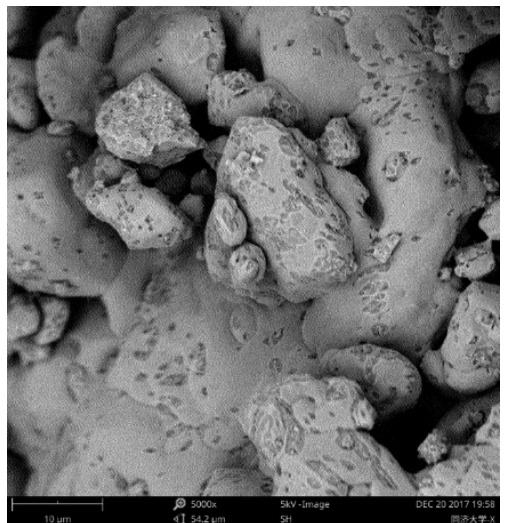

(c) Granular sulfur before reaction

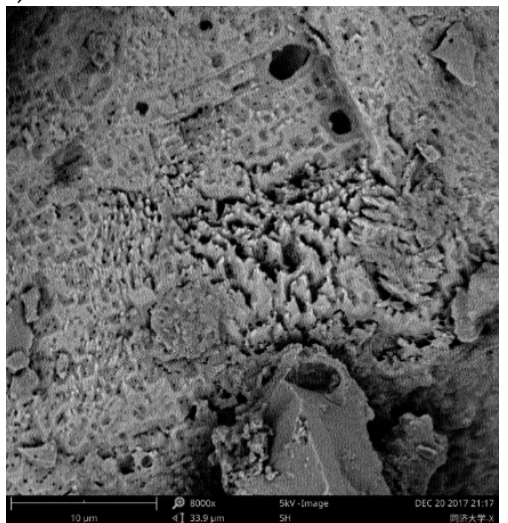

(f) Granular sulfur after reaction

Figure 7. The scanning electron microscopy (SEM) scan result of three kinds of filler (before and after reaction).

The size of spherical bacteria ranged from $0.5 \mu \mathrm{m}$ to $2 \mu \mathrm{m}$, and bacillus were $1-5 \mu \mathrm{m}$ in length and $0.5-1 \mu \mathrm{m}$ in width. As previous studies showed that the denitrification efficiency was influenced by the available sulfur contact area and sulfur particle size, in which smaller sulfur particles corresponded with higher surface area and concomitant higher nitrate removal rates $[48,49]$. Therefore, the well-developed pores and small particle 
size of fillers in the reactor were very suitable for bacterial attachment and increasing the surface area of fillers, improving the removal efficiency of pollutants and especially denitrification performance.

After reaction, a large number of microorganisms were fixed on the surface and inside of the ceramsite, forming a dense biofilm structure, which improved the removal efficiency of pollutants in $\mathrm{HF}_{\mathrm{C}}$. The lamellar structure on the surface of limestone could still be seen, but the crumb-like particles were all consumed to balance $\mathrm{H}^{+}$produced by sulfur autotrophic denitrification, forming a relatively smooth surface structure in some partial areas. The original fine particles on the surface of the sulfur particles almost disappeared completely, forming a rough surface, and many small holes appear, which improves the mass transfer efficiency of sulfur to a certain extent, satisfying the need for dissolved sulfur. Therefore, due to the micropore structure and substantial surface area, like ceramsite and limestone, sulfur can be used as a good filler in constructed wetlands. Meanwhile, sulfur can provide electrons as an electron donor to ensure efficient sulfur autotrophic denitrification.

\section{Conclusions}

In this study, a hybrid constructed wetland system consisted of a conventional constructed wetland $\mathrm{HF}_{\mathrm{C}}$ and a wetland enhanced by sulfur autotrophic denitrification $\mathrm{HF}_{\mathrm{SAD}}$ was built to treat steel rolling wastewater with insufficient carbon source. The average removal efficiencies of DO, COD, and TP in the whole reactor were up to $88.0 \%, 61.4 \%$, and $81.3 \%$, respectively, which had been significantly removed in $\mathrm{HF}_{\mathrm{C}}$. Denitrification was inefficient in $\mathrm{HF}_{\mathrm{C}}$ due to the shortage of carbon source, while $\mathrm{HF}_{\mathrm{SAD}}$ had better removal performance on nitrogen contaminants, whose nitrate removal capacity was around 3-5 times higher than that in $\mathrm{HF}_{\mathrm{C}}$. The analysis result of microbial community structure, observation results of fillers, and monitored sulfate all provided proofs for the occurrence of sulfur autotrophic denitrification and the reasonable application in constructed wetlands. Therefore, incorporating sulfur autotrophic denitrification into constructed wetlands can improve the treatment performance, especially the denitrification capacity of conventional constructed wetland to treat steel rolling wastewater with low $\mathrm{C} / \mathrm{N}$ ratio and other similar industrial wastewater, which is of great significance for water conservation and efficient recycling in steel and iron enterprises.

Author Contributions: Conceptualization, X.L.; formal analysis, T.Z. and X.L.; funding acquisition, J.X., J.R., and J.H.; investigation, T.Z., X.L., and J.R.; methodology, T.Z., X.L., and J.X.; project administration, J.X. and J.H.; resources, J.X. and J.H.; software, J.R., D.S., and Y.G.; supervision, J.X.; validation, T.Z., J.R., D.S., Y.G., and J.H.; visualization, X.L., J.R., D.S., and Y.G.; writing-original draft, T.Z., X.L., and J.R.; writing—review and editing, T.Z., X.L., and J.X. All authors have read and agreed to the published version of the manuscript.

Funding: This research was supported financially by Key Scientific and Technological Project of the Shanghai Science and Technology Committee, China (Grant No.18DZ1203903) and Tongji Architectural Design (Group) Co., Ltd., China (Grant No.2018KY03).

Institutional Review Board Statement: Not applicable.

Informed Consent Statement: Not applicable.

Data Availability Statement: Data is contained within the article.

Conflicts of Interest: The authors declare no conflict of interest.

\section{References}

1. Gu, Y.; Xu, J.; Keller, A.A.; Yuan, D.; Li, Y.; Zhang, B.; Weng, Q.; Zhang, X.; Deng, P.; Wang, H. Calculation of water footprint of the iron and steel industry: A case study in Eastern China. J. Clean. Prod. 2015, 92, 274-281. [CrossRef]

2. Tong, Y.; Zhang, Q.; Cai, J.; Gao, C.; Wang, L.; Li, P. Water consumption and wastewater discharge in China's steel industry. Ironmak. Steelmak. 2018, 45, 868-877. [CrossRef] 
3. Sun, W.; Xu, X.; Lv, Z.; Mao, H.; Wu, J. Environmental impact assessment of wastewater discharge with multi-pollutants from iron and steel industry. J. Environ. Manag. 2019, 245, 210-215. [CrossRef] [PubMed]

4. Xu, J.; Zhao, G.; Huang, X.; Guo, H.; Liu, W. Use of horizontal subsurface flow constructed wetlands to treat reverse osmosis concentrate of rolling wastewater. Int. J. Phytoremediation 2017, 19, 262-269. [CrossRef] [PubMed]

5. Xu, J.C.; Chen, G.; Huang, X.F.; Li, G.M.; Liu, J.; Yang, N.; Gao, S.N. Iron and manganese removal by using manganese ore constructed wetlands in the reclamation of steel wastewater. J. Hazard. Mater. 2009, 169, 309-317. [CrossRef]

6. Huang, X.F.; Ling, J.; Xu, J.C.; Feng, Y.; Li, G.M. Advanced treatment of wastewater from an iron and steel enterprise by a constructed wetland/ultrafiltration/reverse osmosis process. Desalination 2011, 269, 41-49. [CrossRef]

7. Cheng, H.-H.; Whang, L.-M.; Yi, T.-F.; Liu, C.-P.; Lin, T.-F.; Yeh, M.-S. Pilot study of cold-rolling wastewater treatment using single-stage anaerobic fluidized membrane bioreactor. Bioresour. Technol. 2018, 263, 418-424. [CrossRef]

8. Abou-Elela, S.I.; Golinielli, G.; Abou-Taleb, E.M.; Hellal, M.S. Municipal wastewater treatment in horizontal and vertical flows constructed wetlands. Ecol. Eng. 2013, 61, 460-468. [CrossRef]

9. Vymazal, J. Constructed wetlands for treatment of industrial wastewaters: A review. Ecol. Eng. 2014, 73, 724-751. [CrossRef]

10. Vymazal, J.; Kröpfelová, L. Multistage hybrid constructed wetland for enhanced removal of nitrogen. Ecol. Eng. 2015, 84, 202-208. [CrossRef]

11. Zhu, H.; Yan, B.; Xu, Y.; Guan, J.; Liu, S. Removal of nitrogen and COD in horizontal subsurface flow constructed wetlands under different influent C/N ratios. Ecol. Eng. 2014, 63, 58-63. [CrossRef]

12. Wu, S.; Kuschk, P.; Brix, H.; Vymazal, J.; Dong, R. Development of constructed wetlands in performance intensifications for wastewater treatment: A nitrogen and organic matter targeted review. Water Res. 2014, 57, 40-55. [CrossRef] [PubMed]

13. Hang, Q.; Wang, H.; Chu, Z.; Ye, B.; Li, C.; Hou, Z. Application of plant carbon source for denitrification by constructed wetland and bioreactor: Review of recent development. Environ. Sci. Pollut. Res. 2016, 23, 8260-8274. [CrossRef] [PubMed]

14. Cao, S.; Jing, Z.; Yuan, P.; Wang, Y.; Wang, Y. Performance of constructed wetlands with different substrates for the treated effluent from municipal sewage plants. J. Water Reuse Desalination 2019, 9, 452-462. [CrossRef]

15. Li, E.; Jin, X.; Lu, S. Microbial communities in biological denitrification system using methanol as carbon source for treatment of reverse osmosis concentrate from coking wastewater. J. Water Reuse Desalination 2017, 8, 360-371. [CrossRef]

16. Park, J.H.; Kim, S.H.; Delaune, R.D.; Cho, J.S.; Heo, J.S.; Yong, S.O.; Seo, D.C. Enhancement of nitrate removal in constructed wetlands utilizing a combined autotrophic and heterotrophic denitrification technology for treating hydroponic wastewater containing high nitrate and low organic carbon concentrations. Agric. Water Manag. 2015, 162, 1-14. [CrossRef]

17. Song, X.; Wang, S.; Wang, Y.; Zhao, Z.; Yan, D. Addition of $\mathrm{Fe}^{2+}$ increase nitrate removal in vertical subsurface flow constructed wetlands. Ecol. Eng. 2016, 91, 487-494. [CrossRef]

18. Xu, D.; Xiao, E.; Xu, P.; Lin, L.; Zhou, Q.; Xu, D.; Wu, Z. Bacterial community and nitrate removal by simultaneous heterotrophic and autotrophic denitrification in a bioelectrochemically-assisted constructed wetland. Bioresour. Technol. 2017, 245, 993-999. [CrossRef]

19. Sun, H.; Yang, Z.; Wei, C.; Wu, W. Nitrogen removal performance and functional genes distribution patterns in solid-phase denitrification sub-surface constructed wetland with micro aeration. Bioresour. Technol. 2018, 263, 223-231. [CrossRef]

20. Uggetti, E.; Hughes-Riley, T.; Morris, R.H.; Newton, M.I.; Trabi, C.L.; Hawes, P.; Puigagut, J.; García, J. Intermittent aeration to improve wastewater treatment efficiency in pilot-scale constructed wetland. Sci. Total Environ. 2016, 559, 212-217. [CrossRef]

21. Wang, W.; Ding, Y.; Wang, Y.; Song, X.; Ambrose, R.F.; Ullman, J.L. Intensified nitrogen removal in immobilized nitrifier enhanced constructed wetlands with external carbon addition. Bioresour. Technol. 2016, 218, 1261-1265. [CrossRef] [PubMed]

22. Zhang, T.C.; Zeng, H. Development of a Response Surface for Prediction of Nitrate Removal in Sulfur-Limestone Autotrophic Denitrification Fixed-Bed Reactors. J. Environ. Eng. 2006, 132, 1068-1072. [CrossRef]

23. Lv, X.; Shao, M.; Li, J.; Xie, C. Nitrate removal with lateral flow sulphur autotrophic denitrification reactor. Environ. Technol. 2014, 35, 2692-2697. [CrossRef] [PubMed]

24. Wu, D.; Ekama, G.A.; Chui, H.K.; Wang, B.; Cui, Y.X.; Hao, T.W.; van Loosdrecht, M.C.M.; Chen, G.H. Large-scale demonstration of the sulfate reduction autotrophic denitrification nitrification integrated $\left(\mathrm{SANI}{ }^{\circledR}\right)$ process in saline sewage treatment. Water Res. 2016, 100, 496-507. [CrossRef] [PubMed]

25. Montalvo, S.; Huilinir, C.; Galvez, D.; Roca, N.; Guerrero, L. Autotrophic denitrification with sulfide as electron donor: Effect of zeolite, organic matter and temperature in batch and continuous UASB reactors. Int. Biodeter. Biodegr. 2016, 108, 158-165. [CrossRef]

26. Wang, Y.; Bott, C.; Nerenberg, R. Sulfur-based denitrification: Effect of biofilm development on denitrification fluxes. Water Res. 2016, 100, 184-193. [CrossRef]

27. Yang, W.; Lu, H.; Khanal, S.K.; Zhao, Q.; Meng, L.; Chen, G.H. Granulation of sulfur-oxidizing bacteria for autotrophic denitrification. Water Res. 2016, 104, 507-519. [CrossRef]

28. Park, J.Y.; Yoo, Y.J. Biological nitrate removal in industrial wastewater treatment: Which electron donor we can choose. Appl. Microbiol. Biotechnol. 2009, 82, 415-429. [CrossRef]

29. Xu, M.; Liu, W.J.; Li, C.; Xiao, C.; Ding, L.L.; Xu, K.; Geng, J.J.; Ren, H.Q. Evaluation of the treatment performance and microbial communities of a combined constructed wetland used to treat industrial park wastewater. Environ. Sci. Pollut. Res. 2016, 23, 10990-11001. [CrossRef] 
30. Schulz, C.; Gelbrecht, J.; Rennert, B. Treatment of rainbow trout farm effluents in constructed wetland with emergent plants and subsurface horizonal water flow. Aquaculture 2003, 217, 207-221. [CrossRef]

31. Torrijos, V.; Gonzalo, O.G.; Trueba-Santiso, A.; Ruiz, I.; Soto, M. Effect of by-pass and effluent recirculation on nitrogen removal in hybrid constructed wetlands for domestic and industrial wastewater treatment. Water Res. 2016, 103, 92-100. [CrossRef] [PubMed]

32. Masi, F. Enhanced Denitrification by a Hybrid HF-FWS Constructed Wetland in a Large-Scale Wastewater Treatment Plant. Wastewater Treat. Plant Dyn. Manag. Constr. Nat. Wetl. 2008. [CrossRef]

33. Lee, C.g.; Fletcher, T.D.; Sun, G. Nitrogen removal in constructed wetland systems. Eng. Life Sci. 2009, 9, 11-22. [CrossRef]

34. Ma, Y.; Zheng, X.; Fang, Y.; Xu, K.; He, S.; Zhao, M. Autotrophic denitrification in constructed wetlands: Achievements and challenges. Bioresour. Technol. 2020, 123778. [CrossRef]

35. Sorokin, D.Y. Oxidation of Inorganic Sulfur Compounds by Obligately Organotrophic Bacteria. Microbiology 2003, 72, 725-739. [CrossRef]

36. Nemati, M.; Jenneman, G.E.; Voordouw, G. Mechanistic study of microbial control of hydrogen sulfide production in oil reservoirs. Biotechnol. Bioeng. 2001, 74, 424-434. [CrossRef]

37. Park, J.H.; Choi, O.; Lee, T.H.; Kim, H.; Sang, B.I. Pyrosequencing analysis of microbial communities in hollow fiber-membrane biofilm reactors system for treating high-strength nitrogen wastewater. Chemosphere 2016, 163, 192-201. [CrossRef]

38. Zhao, Y.G.; Fang, Y.; Jin, Y.L.; Huang, J.; Ma, X.R.; He, K.Z.; He, Z.M.; Wang, F.; Zhao, H. Microbial community and removal of nitrogen via the addition of a carrier in a pilot-scale duckweed-based wastewater treatment system. Bioresour. Technol. 2015, 179, 549-558. [CrossRef]

39. Kojima, H.; Fukui, M. Sulfurisoma sediminicola gen. nov., sp. nov., a facultative autotroph isolated from a freshwater lake. Int. J. Syst. Evol. Microbiol. 2011, 61, 1651-1655. [CrossRef]

40. Kelly, D.P.; Wood, A.P. Confirmation of Thiobacillus denitrificans as a species of the genus Thiobacillus, in the beta-subclass of the Proteobacteria, with strain NCIMB 9548 as the type strain. Int. J. Syst. Evol. Microbiol. 2000, 50, 547-550. [CrossRef]

41. Vlasceanu, L.; Popa, R.; Kinkle, B.K. Characterization of Thiobacillus thioparus LV43 and its distribution in a chemoautotrophically based groundwater ecosystem. Appl. Environ. Microbiol. 1997, 63, 3123-3127. [CrossRef] [PubMed]

42. Silva, C.C.; Jesus, E.C.; Torres, A.P.; Sousa, M.P.; Santiago, V.M.; Oliveira, V.M. Investigation of bacterial diversity in membrane bioreactor and conventional activated sludge processes from petroleum refineries using phylogenetic and statistical approaches. J. Microbiol. Biotechnol. 2010, 20, 447-449. [PubMed]

43. Ji, G.; Liao, B.; Tao, H.; Lei, Z. Analysis of bacteria communities in an up-flow fixed-bed (UFB) bioreactor for treating sulfide in hydrocarbon wastewater. Bioresour. Technol. 2009, 100, 5056-5062. [CrossRef] [PubMed]

44. Fahrbach, M.; Kuever, J.; Meinke, R.; Kämpfer, P.; Hollender, J. Denitratisoma oestradiolicum gen. nov., sp. nov., a 17betaoestradiol-degrading, denitrifying betaproteobacterium. Int. J. Syst. Evol. Microbiol. 2006, 56, 1547-1552. [CrossRef] [PubMed]

45. Zhang, L.L.; Zhang, C.; Hu, C.Z.; Liu, H.J.; Qu, J.H. Denitrification of groundwater using a sulfur-oxidizing autotrophic denitrifying anaerobic fluidized-bed MBR: Performance and bacterial community structure. Appl. Microbiol. Biotechnol. 2015, 99, 2815-2827. [CrossRef]

46. Shao, M.F.; Zhang, T.; Fang, H.H. Sulfur-driven autotrophic denitrification: Diversity, biochemistry, and engineering applications. Appl. Microbiol. Biotechnol. 2010, 88, 1027-1042. [CrossRef]

47. Zhang, L.L.; Zhang, C.; Hu, C.Z.; Liu, H.J.; Bai, Y.H.; Qu, J.H. Sulfur-based mixotrophic denitrification corresponding to different electron donors and microbial profiling in anoxic fluidized-bed membrane bioreactors. Water Res. 2015, 85, 422-431. [CrossRef]

48. Koenig, A.; Liu, L.H. Kinetic model of autotrophic denitrification in sulphur packed-bed reactors. Water Res. 2001, 35, 1969-1978. [CrossRef]

49. Moon, H.S.; Sun, W.C.; Nam, K.; Choe, J.; Kim, J.Y. Effect of reactive media composition and co-contaminants on sulfur-based autotrophic denitrification. Environ. Pollut. 2006, 144, 802-807. [CrossRef] 